\title{
Hubungan Antara Sumber Daya Manusia Orangtua Dengan Kualitas Pola Asuh yang Diberikan \\ Zulfa Nailli Munna
}

PGPAUD STKIP Modern Ngawi dan zulfanaillimunna@gmail.com

Indah Sulistiyowati

PGPAUD STKIP Modern Ngawi dan indah.sulistiyowati99@gmail.com

\section{Lilik Purwanti}

PGPAUD STKIP Modern Ngawi dan purwanti.lilik@gmail.com

\begin{abstract}
Abstrak
Penelitian ini bertujuan untuk mengetahui hubungan SDM orangtua terhadap tingkat pola asuh yang diberikan orangtua di TK Darmawanita Macanan 2, Kabupaten Ngawi. Populasi dalam penelitian ini adalah walimurid TK Darmawanita Macanan 2. Sampel atau sensus dalam penelitian ini berjumlah 30 walimurid. Penelitian ini merupakan penelitian korelasional dengan pendekatan kuantitatif untuk mengukur SDM orangtua dan tingkat pola asuh. Teknik analisis data yang digunakan adalah analisis korelasi person. Hasil penelitian menunjukkan bahwa terdapat hubungan yang signifikan SDM orangtua terhadap tingkat pola asuh yang diberikan, dengan kontribusi sebesar 0,448 dengan kategori cukup kuat. Berdasarkan hasil penelitian, disimpulkan bahwa hubungan SDM orangtua terhadap kualitas pola asuh yang diberikan adalah cukup kuat.
\end{abstract}

Kata kunci: sumber daya manusia orang tua, pola asuh orang tua.

PENDAHULUAN

Memasuki era globalisasi, sumber daya manusia (SDM) yang berkualitas dan kompetitif sangat diperlukan guna menghadapi tantangan yang semakin besar. SDM yang berkualitas dapat diperoleh melalui pendidikan. Indonesia dihadapkan pada tantangan kualitas pendidikan yang masih rendah. Penduduk yang memanfaatkan program pendidikan menurun pada jenjang pendidikan, sehingga pemerintah Indonesia menetapkan Undang-Undang Nomor 20 tahun 2003 pasal 6 ayat 1 bahwa "Setiap warga negara yang berusia tujuh sampai dengan lima belas tahun wajib mengikuti pendidikan dasar". Penetapan undang-undang tersebut merupakan salah satu cara pemerintah dalam peningkatan APM dengan memberikan kesempatan seluas-luasnya pada penduduk untuk mengenyam pendidikan. Setiap manusia berhak memperoleh pendidikan.
Pendidikan sebagai cara untuk mengembangkan keterampilan, kebiasaan, dan sikap-sikap yang diharapkan dapat membuat seseorang menjadi lebih baik serta menjadi bekal kehidupannya. Pendidikan yang berkualitas dapat di ukur melalui prestasi belajar di sekolah. Prestasi belajar dapat dicapai melalui peran serta berbagai pihak antara lain orangtua, masyarakat, guru, pemerintah, dan peserta didik. Dalyono (2007: 130) menyatakan bahwa faktor keluarga sangat besar pengaruhnya terhadap prestasi belajar anak. Tinggi rendahnya pendidikan orangtua, besar kecilnya penghasilan, cukup atau kurang perhatian dan bimbingan orangtua, rukun atau tidaknya hubungan kedua orangtua dengan anakanak, dan tenang atau tidaknya situasi dalam rumah turut mempengaruhi prestasi belajar anak. Orangtua sebagai pendidik di lingkungan keluarga harus memiliki kualitas diri. Ada juga penelitian 
yang menyatakan Latar belakang pendidikan seseorang menentukan kecerdasan dalam pengambilan keputusan dan pengelolaan ekonomi (Sitorus, 2017).

Pendidikan sebagai upaya untuk meningkatkan kualitas diri seseorang. Pendidikan dapat diperoleh melalui pendidikan formal maupun pendidikan nonformal. Pendidikan formal memiliki jenjang pendidikan yaitu sekolah dasar, menengah, dan perguruan tinggi. Setiap jenjang memiliki peran dan program yang berbeda-beda. Manurung (1995: 53) menjelaskan bahwa tinggi rendahnya pendidikan orangtua mempengaruhi pola pengasuhan yang diterapkan orangtua pada anaknya. Hal tersebut sejalan dengan kemampuan literasi orang tua, dimana keluarga yang memiliki latar belakang pendidikan yang tinggi cederung memiliki tingkat literasi yang tinggi pula (Laksono et al., 2019a). Perhatian dan bimbingan orangtua dipengaruhi oleh pendidikan yang melatarbelakangi orangtua. Orangtua yang berpendidikan tinggi memberikan bimbingan dan perhatian yang optimal, sehingga dapat meningkatkan motivasi anak dalam berprestasi. Orangtua harus memahami kondisi anaknya agar dalam memberikan aturan, perhatian, arahan, kasih sayang, bimbingan, dan perlindungan sesuai dengan yang dibutuhkan anak tersebut.

Pola asuh yang diterapkan pada setiap keluarga berbeda-beda. Orangtua mempunyai ciri khas masing-masing dalam mengasuh anak. Barara (2012: 2) mengemukakan bahwa pola asuh orangtua yang bersifat terlalu ketat atau kaku, anak tersebut akan memberontak karena merasa dirinya dikekang. Memberikan segala sesuatu yang dibutuhkan anak, mengakibatkan anak menjadi tergantung pada orangtua dan tidak bisa membuat keputusan sendiri, sedangkan anak dibiarkan terlalu bebas akan membuatnya menjadi tidak tahu aturan. Orangtua akan melakukan apapun untuk memenuhi harapan dan keinginan anak, segalanya akan diusahakan, sehingga lupa bahwasanya orangtua menerapkan pola asuh yang berlebihan atau kurang tepat.

\section{METODE}

Penelitian ini merupakan penelitian korelasional yang menggambarkan suatu pendekatan umum untuk penelitian yang berfokus pada penaksiran pada kovariasi diantara variabel yang muncul secara alami. Pendekatan yang digunakan dalam penelitian ini adalah pendekatan kuantitatif yang menganalisis data dengan alat statistik dalam bentuk angka-angka. Penelitian ini bertujuan untuk mencari hubungan antara variabel bebas dalam penelitian ini adalah SDM orang tua (X), sedangkan variabel tergantung atau terikatnya adalah kualitas pola asuh (Y).

Penelitian ini dilaksanakan di TK Darmawanita Macanan 2 Dusun Ngijo, Desa Macanan, Kecamatan Jogorogo, Kabupaten Ngawi. Populasi dalam penelitian ini adalah Walimurid TK Darmawanita Macanan 2 Dusun Ngijo, Desa Macanan, Kecamatan Jogorogo, Kabupaten Ngawi. Walimurid yang menjadi sempel responden ada 30 responden. Pengumpulan data dalam penelitian ini menggunakan angket (kuesioner) yaitu angket secara langsung dan tertutup dengan empat alternatif jawaban. Angket ini digunakan untuk memperoleh data mengenai SDM orangtua dan kualitas pola asuh orangtua. Instrumen yang digunakan dalam penelitian ini adalah lembar angket SDM orangtua dan pola asuh orangtua. Penelitian ini menggunakan teknik analisis deskriptif dan analisis inferensial. Analisis deskriptif digunakan untuk melihat gambaran data dari masing-masing variabel yang dinyatakan melalui mean, median, modus, distribusi 
frekuensi dan histogram. Pengolahan data dalam penelitian ini menggunakan program

\section{HASIL DAN PEMBAHASAN \\ Hasil}

Dalam penelitian ini dapat dilihat bahwa responden yang berjenis kelamin lakilaki ada 2 responden atau $6,7 \%$ dan perempuan 28 orang atau $8,3 \%$ nya. Sedangkan yang 2 atau $6,7 \%$ laki-laki ini sebagai ayah dan 28 atau 8,3\%nya ini sebagai ibunya. Karena bervariasinya umur responden disini kami kelompokkan menjadi 3 yaitu yang berusia kurang dari 25 tahun ada 4 orang atau 13,3\%,yang berusia 26 sampai 30 tahun ada 11 orang atau $36,7 \%$, dan yang berusia lebih dari 31 tahun ada 15 orang atau 50\%nya, jadi dapat dilihat bahwa kebanyak dari responden adalah mereka yang berusia lebih dari 30 tahun.

Latar belakang pendidikan responden yang lulusan SD ada 4 orang atau sebanyak 13,3\% adalah lulusan SD, Lulusan SMP 11 orang 36,7\%nya lulusan SMP, lulusan SMA 12 orang atau 40\% lulusan SMA sedangkan yang lulusan perguruan tinggi hanya 3 orang atau hanya $10 \%$ nya saja dapat kita lihat bahwa kebanyakan responden adalah lulusan SMA yaitu 40\%nya sedangkan yang lulusan perguruan tinggi sangat sedikit yaitu hanya 3

\section{SPSS versi 23.0.}

orang saja. Berhubung responden mayoritas perempuan maka sebanyak $73,3 \%$ yaitu 22 orang dari mereka adalah bekerja mengurus rumah tangga, yang bekerja sebagai petani ada 2 orang atau $6,7 \%$, sedangkan yang wirasuwasta ada 3 orang atau $10 \%$, yang bekerja sebagai wirasuwasta $3,3 \%$ nya saja yaitu 1 orang, dan pekerjaan lainnya disini sebagai PNS ada 2 orang atau $6,7 \%$.

Alamat mereka ada yang dari Desa Macanan Dusun Ngijo 20\% yaitu 6 orang yang dari Ngijo, 405 dari responden yaitu dari Dusun Sanan 12 orang, dari Dusun Mindi 6 orang yaitu 205 dari responden, dari Dusun Jeblokan 1 orangkalau dipresentasekan menjadi 3,3\%, dan responden yang dari selain Desa Macanan ada 5 orang, Penghasilan mereka kita kelompokkan menjadi tiga yaitu kurang dari Rp. 500.000 ada 22 orang atau bisa dikatakan bahwa $73,3 \%$ nya, yang berpenghasilan Rp. $\quad 600.000$ sampai Rp.1.000.000 perbulan ada 5 orang yaitu $16,7 \%$ nya responden, sedangkan yang berpenghasilan lebih dari Rp. 1000.000 ada 2 orang yaitu $10 \%$ dari responden.

Latar belakang pendidikan responden dapat kita lihat dari hasil penelitian sebagai berikut:

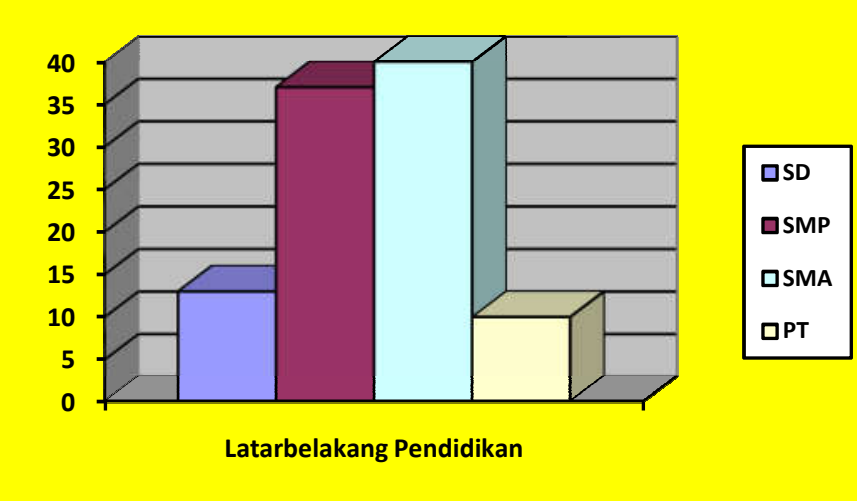

Gambar 1. Latar belakang pendidikan responden 


\section{Sumber Daya Orangtua}

Setelah analisis data dapat kita lihat bahwa SDM orangtua walimurid TK Darmawanita macanan 2 adalah berkualitas sangat baik, ditunjukkan bahwa responden yang memiliki tingkat SDM baik ada 13 yaitu $43 \%$ dari responden, dan sisanya 57\% responden atau 17 orang memiliki tingkat SDM yang sangat baik.

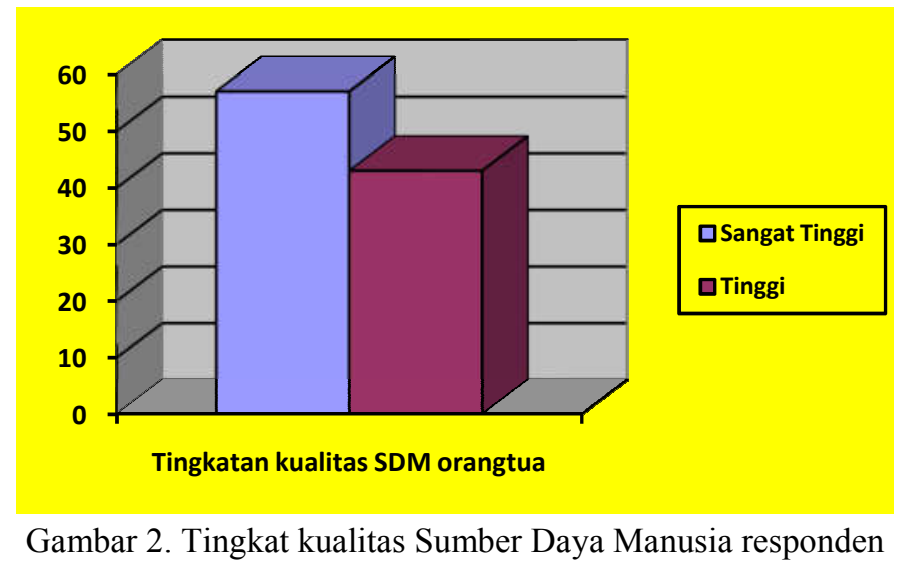

\section{Kualitas Pola Asuh Yang Diterapkan}

Berdasarkan analisis dapat kita lihat bahwa tingkat kualitas pola asuh yang diterapkan responden memiliki kualitas yang baik, yaitu ditunjukkan dengan jumlah tingkat kualitas pola asuh yang baik ada 15 orang
$50 \%$ nya responden memiliki tingkat pola asuh yang baik, dan yang 50\%nya lagi dari responden yaitu 15 responden memiliki kualitas pola asuh yang sangat baik sehingga dapat kita gambarkan dalam sebuah histogram sebagai berikut :

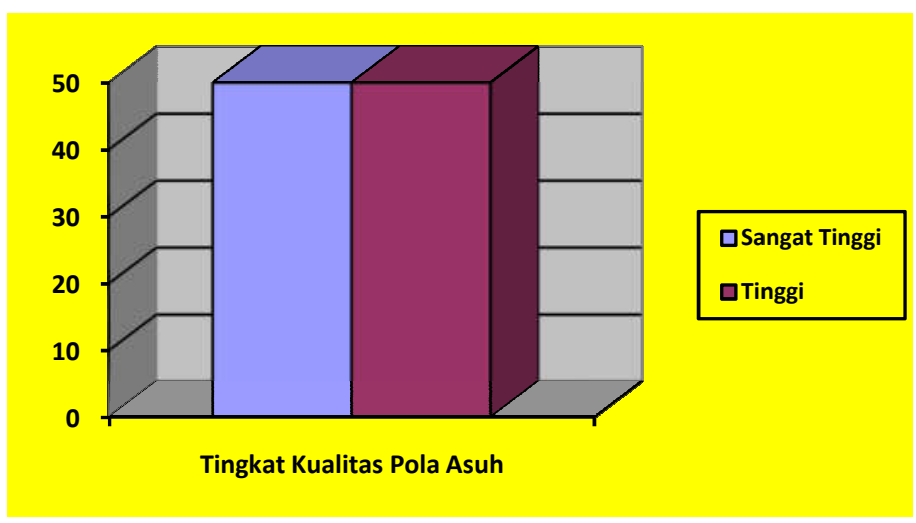

Gambar 3. Tingkat kualitas pola asuh yang diterapkan

Hubungan Sumber Daya Manusia Orangtua Terhadap Tingkat Pola asuh yang Diberikan

\begin{tabular}{|ll|r|r|}
\hline & & Sdm Orangtua & Pola Asuh \\
\hline Sdm Orangtua & Pearson Correlation & 1 & $.448^{*}$ \\
& Sig. (2-tailed) & & .013 \\
& $\mathrm{~N}$ & 30 & 30 \\
\hline Pola Asuh & Pearson Correlation & $.448^{*}$ & 1 \\
& Sig. (2-tailed) & .013 & \\
& $\mathrm{~N}$ & 30 & 30 \\
\hline
\end{tabular}


Dari hasil penelitian ini diperoleh korelasi antara SDM Orangtua terhadap kualitas pola asuh yang diterapkan sebesar 0,448 yang bertanda positif, mempunyai korelasi atau hubungan cukup kuat. Berdasarkan analisis di atas, dapat diketahui juga bahwa terdapat hubungan positif dan signifikan tingkat SDM orangtua dengan pola asuh yang diberikan orangtua. Semakin baik tingkat SDM orangtua maka semakin baik pula kualitas pola asuh yang diberikan.

\section{Pembahasan}

Berdasarkan hasil penelitian di atas menunjukkan bahwa sebagian besar orangtua di TK Darmawanita macanan 2 memiliki latar belakang pendidikan SMA/SMK derajat. Hal ini menunjukkan bahwa latar belakang pendidikan berhubungan dengan kualitas pola asuh yang diterapkan, sehingga semakin tinggi tingkat pendidikan orangtua semakin tinggi pula kualitas pola asuh yang diterapkan. Orang tua dengan latar belakang pendidikan tinggi akan bersikap lebih siap dalam mengasuh anaknya, karena pengetahuan yang luas diperoleh melalui kegiatan membaca artikel ataupun mengikuti kemajuan mengenai perkembangan anak. Orang tua yang berpendidikan tinggi juga lebih bisa, berpikir kritis atas apa yang mereka dapatkan, sehingga mereka bisa memilah apa yang baik dan tidak untuk mereka lakukan terhadap anaknya. (Hetherington dan Parke, 1979).

Hal ini juga sesuai dengan deskripsi teori dari Manurung (1995:53), ada beberapa faktor yang mempengaruhi pola asuh orang tua yaitu latar belakang pola asuh orang tua, tingkat pendidikan orang tua dan status ekonomi dan pekerjaan orang tua. Menurut Manurung bahwa pola asuh dipengaruhi oleh tingkat pendidikan orang tua karena orang tua yang berpendidikan tinggi akan lebih mudah untuk mendapatkan informasi mengenai pola asuh, mereka bisa menyampaikan dengan baik dan bisa menerapkannya kepada anak dengan disesuaikan keadaan psikis dan fisik dari masing-masing anak. Penelitian ini juga sesuai dengan penelitian dari Niniek Kharmina yang berjudul hubungan antara tingkat pendidikan orang tua dengan orientasi pola asuh anak usia dini. Dalam mengasuh anak orang tua bukan hanya mampu mengkomunikasikan fakta, gagasan, dan pengetahuan saja, melainkan membantu menumbuhkembangkan kepribadian anak (Riyanto, 2002). Orangtua sangat berperan untuk memberikan pengasuhan yang baik pada putra putrinya terutama ibu yang memiliki peran sangat penting untuk pengasuhan putra putrinya karena ibu merupakan sekolah pertama untuk putra putrinya, hal ini sesuai dengan pernyataaan Menurut Sofian (2014), perkembangan anak tidak lepas dari peran penting orang tua, dimana orang tua bertanggung jawab dalam segala hal terutama peran seorang ibu dalam mengasuh dan mendidik karena ibu sebagai guru pertama bagi anak-anaknya.sehingga ketika ibu memili latar belakang pendidikan yang baik maka perkembangan anak tidak perlu diragukan lagi.

Menurut Yani dkk. (2011), selama proses mengasuh dan mendidik anak akan muncul suatu kedekatan antara orang tua dengan anak, tetapi tidak semua orang tua memberikan kualitas pengasuhan yang efektif kepada anak-anak mereka. Hal ini menimbulkan pola kedekatan yang berbeda di setiap orang tua dan anak. Pola asuh tak lepas dari faktor karakter dari masing-masing orang tua, usia orang tua, jumlah anak yang diasuh serta tingkat pendidikan orang tua lebih dominan dalam mewarnai pola asuh yang diterima anak-anak pada umumnya. Berdasarkan hasil di atas menunjukkan bahwa mayoritas tingkat sumber daya manusia 
orangtua TK Macanan 2 dalam kategori sangat baik. Hal ini menunjukkan bahwa tingkat sumber daya manusia berhubungan dengan kualitas pola asuh yang diterapkan, sehingga semakin tinggi sumber daya seseorang maka semakin tinggi pula kualitas pola asuh yang diterapkan. Orang tua yang sudah mempunyai pengalaman sebelumnya dalam mengasuh anak akan lebih siap menjalankan peran asuh, selain itu orang tua akan lebih mampu mengamati tanda-tanda pertumbuhan dan perkembangan yang normal (Supartini, 2004). Pemahaman orang tua yang salah satunya ditujukkan dengan tingkat literasinya memiliki pengaruh yang cukup signifikan dalam tingkat ketahanan keluarga (Laksono et al., 2019b).

Dari hasil analisis diketahui bahwa terdapat konstribusi yang signifikan SDM Orangtua terhadap kualitas pola asuh yang diterapkan. Dari hasil penelitian ini diperoleh korelasi antara SDM Orangtua terhadap kualitas pola asuh yang diterapkan sebesar 0,448 yang mempunyai korelasi atau hubungan cukup kuat. Berdasarkan analisis di atas, dapat diketahui juga bahwa terdapat hubungan positif dan signifikan tingkat SDM orangtua dengan pola asuh yang diberikan orangtua. Semakin baik tingkat SDM orangtua maka semakin baik pula kualitas pola asuh yang diberikan, Hasil penelitian ini diperkuat dengan kajian teori, menurut Agus Wibowo (2012: 116) pola asuh sebagai pola interaksi anak dengan orangtua yang meliputi kebutuhan fisik (makan, minum, dan lain-lain) dan non fisik (perhatian, empati, kasih sayang, dan sebagainya).

\section{PENUTUP}

\section{Kesimpulan}

Setelah penelitian ini dapat kita tarik kesimpilan bahwa mayoritas responden walimurid TK macanan 2 adalah lulusan SMA/SMK sederajat yang mana latar belakang pendidikan akan mempengaruhi tingkat SDM seseorang. Berdasarkan analisis di atas, dapat disimpulkan bahwa terdapat hubungan positif dan signifikan tingkat SDM orangtua dengan pola asuh yang diberikan orangtua. Semakin baik tingkat SDM orangtua maka semakin baik pula kualitas pola asuh yang diberikan.

\section{Saran}

Berdasarkan hasil penelitian dan kesimpulan di atas, maka dapat diberikan saran sebagai berikut: Terdapat hubungan positif dan signifikan tingkat SDM orangtua dengan pola asuh yang diberikan orangtua, maka untuk meningkatkan kualitas pola asuh yang diberikan sebaiknya orangtua meningkatkan kualitas SDM mereka sebagai orangtua selain dengan pendidikan formal orangtua juga bisa meningkatkan SDM dengan membaca artikel dan sering mengikuti seminar- seminar Berdasarkan penelitian ini disarankan tingkat pendidikan orang tua yang baik, disiplin serta bijaksana akan menghasilkan Pola Asuh yang lebih baik. Ini terdorong oleh adanya suatu kebutuhan akan dorongan dan upaya untuk meningkatkan kualitas pola asuh anak agar tejadi satu keutuhan serta keharmonisan kerja di sekolah, sehingga proses dan out put pendidikan bisa maksimal. Pengaruh positif bahwa jika tingkat pendidikan orang tua semakin baik dalam mendidik maka semakin baik pula hasil pola asuh terhadap anak.

\section{DAFTAR PUSTAKA}

Agung, A. A. Gede. 2010. Penelitian Konvensional (Ex Post Facto/Survei dan Eksperimental). Singaraja: Undiksha, Singaraja.

Agung, A. A. Gede. 2011. Metodologi Penelitian Pendidikan. Singaraja: Undiksha, Singaraja. 
Candiasa, I Made. 2010. Statistik Multivariat

Disertai Aplikasi SPSS. Singaraja:

Universitas Pendidikan Ganesha

Laksono, B. A., Supriyono, S., \& Wahyuni, S. (2019a). Literasi Finansial Dan Digital Keluarga Pekerja Migran Ditinjau Dari Latar Belakang Pendidikan. Jurnal Pendidikan Dan Kebudayaan, 4(2), 139151.

https://doi.org/10.24832/jpnk.v4i2.1291

Laksono, B. A., Supriyono, \& Wahyuni, S.

(2019b). Tinjauan Literasi Finansial dan Digital pada Tingkat Ketahanan Keluarga Pekerja Migran Indonesia. Jurnal Penelitian Kesejahteraan Sosial, 18(2), 123-134.

Riduwan. 2008. Metode dan Teknik

Menyusun Thesis. Bandung: Alfabeta.

Sugiyono. (2013). Metode Penelitian

Pendidikan: Pendekatan Kuantitatif,

Kualitatif, dan R\&D. Bandung: Alfabeta.

Supartini, Y. 2004 Buku ajar konsep dasar keperawatan anak. Jakarta. EGC.

Vera Farah Barara. (2011). Salah Asuh Orangtua Bisa Jadi Masalah Anak di Kemudian Hari. diakses dari http//:health.detik.com. pada Jumat, 25 Maret 2016. 